\section{Role of Spiritual Medicine as Integrative Medicine in Patients with Cancer (Review)}

\section{Raúl H Morales-Borges* and Marilyn Rodríguez-Díaz}

Integrative Optimal Health of Puerto Rico, Puerto Rico, USA

\begin{abstract}
Spirituality has a prominent role in the lives of most cancer patients, whether they formally represent truthfully to a specific religion and belief. As a result, the oncologists and the palliative care teams are called upon to support families who are experiencing their neardeath time and strive to make sense of their lives during a healthcare crisis. Integrative medicine can augment their care we offer our patients by supporting the human spirit within the frail bodies with which we entrusted. Psycho-Oncology, Oncology Nursing and Medical Oncology play a vital role in spiritual medicine. So, we reviewed the importance of spirituality in Integrative Medicine with cancer patients, and we encouraged to create more curricula and doing clinical trials on this topic.
\end{abstract}

Keywords: Cancer; Healing; Integrative Medicine; Integrative Oncology; Spirituality; Spiritual Medicine

\section{Introduction}

The English word "Healing" relates to the Anglo-Saxon hoelan, and is used in several senses: Literally, it means making whole or well, as in Ecclesiastes 3:3. In this way, it occurs in the prayers for restoration of health (Numbers 12:13; Psalms 6:2; Jeremiah 17:14); and, in the declarations of God's power to restore health (Deuteronomy 32:39; 2 Kings 20:5-8).

Metaphorically, it applies to the restoration of the feeling to a deity and to the repair of the injuries caused by $\sin$ (Psalms 41:4; Jeremiah

*Corresponding author: Raúl M Morales-Borges, Integrative Optimal Health of Puerto Rico, 29 Washington Street Suite \#107, San Juan, Puerto Rico, 009071509, USA, Tel: +1 787220412; Fax: +1 7877230554; E-mail: raul.morales.borges@gmail.com; raul@nairesearch.org

Citation: Morales-Borges RH, Rodríguez-Díaz M (2019) Role of Spiritual Medicine as Integrative Medicine in Patients with Cancer (Review). J Altern Complement Integr Med 5: 086.

Received: December 20, 2019; Accepted: December 27, 2019; Published: December 31, 2019

Copyright: (c) 2019 Morales-Borges $\mathrm{RH}$, et al. This is an open-access article distributed under the terms of the Creative Commons Attribution License, which permits unrestricted use, distribution, and reproduction in any medium, provided the original author and source are credited.
$30: 17)$; restoration and deliverance of the afflicted land (2 Chronicles 7:14; Isaiah 19:22) and forgiveness of $\sin$ (Jeremiah 3:22).

In the New Testament, therapeuo was used ten times in describing our Lord's miracles and translated to mean "healing". Laomai was used to express spiritual healing (Matthew 13:15; Luke 5:17; John 12:40), and of curing human disease (John 4:47). Diasozo, meaning "to heal thoroughly", was used in Luke 7:3 of the King James Version, whereas in the Revised Version (British and American), was expressed as "save". Healing was used 33 times in the Old Testament by presenting the same Hebrew word in a variety of meanings. It used for purification of an offense or breach of the ceremonial law (2 Chronicles 30:20); and to express the purification of water which had caused disease (2 Kings 2:21-22) as stated in The Bible at in Exodus 23:25 - "The Lord will keep you free from every disease" [1,2]. Healing has mentioned for years, and it's very close to the term spirituality, which means the activity of making a person healthy without using medicines or other physical methods, sometimes as part of a religious ceremony. Spiritual healing has an ancient pedigree, with much evidence of success [3].

In medicine, particularly with cancer patients, we pray for their healing despite applying the best standard treatment and care as well as when they are in the terminal phase. Spirituality plays a prominent function in the lives of most palliative patients, whether they formally correspond to a specific faith and belief. As a result, the alleviator care team is called upon to support families who are experiencing their near-death and struggling to make sense of their lives during a healthcare crisis. Whether we subscribe to the ubiquitousness of a soul or not, integrative medicine can increase the care we offer our patients by encouraging the human life principle within the frail Bodies with which we are entrusted [4]. So, in this paper, we reviewed the importance of spirituality in Integrative Medicine with cancer patients, and we encouraged them to do clinical trials on the topic.

\section{Background on Spirituality}

As per Tacey, the sacred life is no longer a specialist concern, restricted to those who belong to religious traditions [5]. The spirituality revolution is an unprompted movement in society, a significant new interest in the reality of spiritualism and its healing effects on life, health, community and wellbeing. The fields of public health, social work and psychology are now facing a crisis, where earthly-trained healers are no longer convinced how to respond to this new and urgent roar for spiritual essence. Psychiatrists are whispering about a 'spirituality gap', a discernible split between the professionals who are trained in secular pieces of knowledge and methods and the wider soul-searching community who are no longer content with reductive answers to human problems. Some educators and social scientists fear that this new cry for spirituality is itself part of the sickness of society, that we are becoming deluded and losing the plot. Nevertheless, this is not the case; instead, some of our established social attitudes have mistaken: as a community, we have forgotten, buried, or repressed too much of our human heritage, too much of our ancient past. 
Gorsuch and Miller stated that clinicians should assess clients' spirituality [6]. The role of spiritual processes as the prognostic, contextual, outcome and intervention variables in the treatment of all the patients. The authors begin with broader approaches and proceed to more specific measures organized around three broad assessment domains cognitive, behavioral and experiential.

\section{Psycho-Oncology}

Psycho-oncology is a field of study and practice at the intersection of lifestyle, psychology and oncology. It is concerned with aspects of cancer that go beyond medical treatment and include lifestyle, psychological and social issues of cancer treatment.

The debate was rigorous in psycho-oncology about whether spiritual, existential and psychosocial are the broadest terms of academic research discourses investigating meaning and purpose. In contrast, in a call-to-action email from the International Society of Psycho-Oncology, the word "soul", was included. The current essay highlighted the historical and contemporary uses of "soul". They suggest that the re-emergent soul signifies a tacit quest for an "intangible" that seems missing in current constructs of clinical domains reflected in the vigour of the debates. It suggested that the re-emergence of the pre-Medieval meaning (s) of the notion of soul affirms a growing need for integrative paradigms on "being human" to guide psycho-oncology practitioners and their researches. As a paradigmatic example, a clinical support group called Soul Medicine said to have employed the term soul to open the more marginal discourses about experiences of illness arising from philosophical reflection, arts, humanities and spirituality within a clinical oncology context. A link between soul and wisdom suggested for further exploration with the view that phronesis (the virtue of practical knowledge), an emerging concept in health professional education research, is of ultimate value to the people psycho-oncology Seeks to serve. This group holds that garnering wisdom from the expertise of those living with cancer should be its central aim [7].

\section{Spirituality and Oncology Nursing}

Oncology nurses provide spiritual care in a variety of ways that often are personal and private, yet they do so infrequently and with some discomfort $[8,9]$. Effort in this practice has not maximized, and more studies are recommended in the field.

\section{Challenges and Demands in Healing Spirituality and Medicine}

Necessary changes have been taking place both within the church and within medicine. Issues relating to health and wellbeing, have questioned the fundamental practices of these two institutions, principally about the definition of health and who is to be involved in healing. This paper contended that those issues raised at times of transformation when the old order, whether it be in the church or medicine, is being challenged. From the community, there is a growing demand for involvement in health issues and initiatives promoting a healthy lifestyle. Within the church, there were demanded by the laity to be actively involved in the life of the church, and for lay ministries to be recognized.

Communities were eager to market decisions about matters which affect their daily lives and no longer willing to abdicate decision making to licensed and expert professionals who might be far ahead of them in terms of educational background, social class and experience. This does not mean that there is a revolt by individuals against health care professionals or clergymen. It proposed that these health experts should become facilitators and informed advisers. Both medicine and spiritual healings can bring about the conditions under which healing can occur. Even though the social implications of healing such as an individual's integration into the community, the maintenance of a pool of labour, and the psychological consequences of improving such as happier, contented patients and relieve of distress, it is far more difficult in modern society to articulate the spiritual implications of healing. Spiritual healing appears to be of particular benefit when it is at the request of the patient and family, and for the elderly, the chronically ill and dying. Recognizing a patient's beliefs and facilitating health care practice, which considers those beliefs appear to be an essential initiative in the management of suffering and loss [10].

It was observed in the previous years that 244 (49\%) out of 495 respondents used Complementary and Alternative Medicine (CAM) for oncology treatment. A logistic statistical method model indicated that CAM use was associated with younger age, Jewish religion, and higher cancer-related spiritual quest with values ranging from 1.236 - 3.575 for EXP (B) $[p=0.006$ at $95 \%$ confidence interval]. When compared with patients with the lower spiritual quest, CAM users with higher spiritual journeys expressed more expectations of CAM counselling in various themes, namely improving the working and bricking with illness, lessening chemotherapy side-effects and supporting the patient and family emotionally and spiritually. Besides, they expected their social worker to be more involved in building the CAM treatment plan compared to patients with the average spiritual quest at $35.3 \%$ versus $16.3 \%(\mathrm{p}=0.038)$. A higher degree of the spiritual journey was associated with augmented CAM use and higher expectations from CAM providers and social workers in the context of CAM integration within cancer care [11].

\section{Spirituality and Medicine - Curricular Projects}

An increasing number of medical schools are offering courses in spirituality in medicine. In 1994, only 17 out of the 126 accredited US medical schools offered courses on spirituality in medicine. By 1998, this number went up to 39 , by 2004 , to 84 Schools and by 2011 , more than $75 \%$ of medical schools had integrated spirituality related topics into their training programs [12]. These triggered similar initiatives internationally [13]. Growing interest was going on in Spiritual Medicine, and there are programs and centres offering certifications and fellowships [14-18].

\section{Research and Spiritual Medicine}

Research is increasingly demonstrating a relation between religion/spirituality and health [19]. Physicians should be aware of this research and understand their clinical implications. It is recommended that a brief spiritual history taken from all patients with severe or chronic illnesses. If religious issues are present, referral to chaplains or other spiritual care experts is also recommended.

Religious and spiritual variables are not used in medical research [20]. For example, a review of 2,348 studies published in 4 major psychiatry journals between 1978 and 1982 revealed that only 59 $(2.5 \%)$ used a religious or spiritual variable. A later review of the same journals from 1991 to 1995 revealed that only $1.2 \%$ used such a variable. Similar reports have had shown that only $3.5 \%$ of family 
practice studies, $1.1 \%$ of internal medicine studies, $11.8 \%$ of adolescent health studies, $10.0 \%$ of mental health nursing studies and $3.6 \%$ of gerontology studies used religious or spiritual variables. Neglecting religious and spiritual variables in medical research may partly be due to the reliance on the biomedical model in which physical evidence is paramount. The biomedical model is excellent for describing precise disease mechanisms (e.g., viral illnesses) with its deficiency and difficulty in accounting for psychological, sociological, and spiritual factors that influence most, if not all, diseases. Most of the studies that had considered the effects of religious or spiritual factors on health used measures of religious involvement such as frequency of attendance at religious services and scales of religiosity and not means of spirituality. The main reason for this practice is the greater consensus on how to define and measure religious involvement as opposed to spirituality.

\section{New Trends in Spiritual Medicine towards the New Millennium}

As per Ribaudo and Takahashi, a recursive learning process in that knowledge gained by the theoretical exploration of spirituality should be followed by the practical application of that knowledge [21].

The history of the integration of religion and spirituality into psychotherapy has driven by several trends [22]. All push toward more religious and spiritual diversity for both clients and therapists. Pressure toward a variety of clients has come from the introduction of Eastern religion and philosophy, which has been mainly due to massive shifts in immigration and to worldview shifts of the 1960s and 1970s. Among therapists, the cognitive revolution made it more reasonable to deal explicitly with values; hence religion and spirituality have been addressed more openly than in previous decades. Economic pressures managed care; in particular have changed practice to accept, if not demand, practitioners willing to integrate religious and spiritual considerations. The openness of secular therapists to spiritual, but less often ethical, approaches has been fuelled by multicultural evolution. The popularity and availability of peer counselling have moved much, helping away from value-free or value-neutral to a value-informed perspective. These social trends have set up two camps: a secular field emphasizing spirituality and a religious camp focused on religions [22].

Spirituality can be an essential component in the way patients countenance chronic diseases, suffering and loss. Physicians need to address and be attentive to all distress of their patients physical, emotional and spiritual. Doing so is part of the delivery of compassionate care. I think we can be better physicians and real partners in our patients' living and their death if we can be kind: if we truly listen to their hopes, their fears and their beliefs and incorporate these beliefs into their therapeutic plans [23].

Nurses often make a relationship between spirituality and religion. They documented in nursing records when comments about the patient's religious faith are placed in the space devoted to spirituality. While religion may inform and offer direction to an individual's spirituality, the two concepts are not the same. In positions of analogy, hydrogen and oxygen combine to make water, although each brings its defining characteristics to balance the chemical equation. Thus, there may be a synergy and symbiosis between religion and spirituality, but the essence of each remains unique; indeed, a person's spirituality can thrive irrespective of a religious creed orthodox or otherwise.
The authors developed a narrative that articulates and offers the defining characteristics of spirituality. That issue will be coupled with a framework that seeks to explain the workings and dynamics of spirituality in clinical nursing [24].

Part of alternative medicine's appeal is its claim to fulfil people's needs for spirituality and the transcendent. The interest in spirituality among Americans is staggering. Several recent studies have indicated that more than 90 percent of Americans pray and 95 percent claim that their prayers are answered. Furthermore, more than three-quarters of all Americans believe God answers prayer for healing an incurable illness and 14 percent declare they have experienced such healing. According to a study cited in the June 2000 issue of the New England Journal of Medicine, three-quarters of hospitalized patients wanted physicians to consider their spiritual needs [25]. One survey found that 99 percent of family physicians believed that religious belief could contribute to patients' healing. Ninety-two percent of HMO professionals believed likewise. About two-thirds of these same physicians and HMO professionals said they used prayer or meditation themselves when they are ill. The re-emergence in interest regarding spiritual matters raises questions about the provision of "spirituality" by healthcare professionals. Medicine's traditional focus on the physical dimensions of health and healing is increasingly being extended to encompass patients' emotional, relational, and spiritual concerns as well. As a result, the door has been opened for discussions between physicians and patients, which would not have been possible a few years ago. Although this shift presents Christian physicians with an excellent chance to share their faith, a real danger exists in that patients might become open to matters of faith because they believe it may offer health benefits. This would be, to paraphrase CS Lewis, putting second things first. While we can generally expect that faith in God will have spiritual, physical emotional and relational benefits, belief in God should be landed simply in faith and trust in Him and not in an expectation of resultant health benefits. The "second things" must not be regarded as "first things" in our lives.

There is a real danger that when spirituality and health are linked, health can become the measure of one's spirituality. Those who are ill may be having insufficient faith to produce healing. This can serve out too much guilt on the infirm, especially if they become terminally ill. However, the Bible rejects such an absolute connection between faith and health, maintaining that times of suffering and pain can result in spiritual growth: "Consider it pure joy, my brothers, whenever you face trials of many kinds because you know that the testing of your faith develops perseverance. A determination must finish its work so that you may be mature and complete, not lacking anything" (Jam. 1:2-4). Christians should not expect freedom from suffering because of their faith but should expect additional pain because of their faith (1 Peter 4:12-19). Alternative medicine also brings into sharp focus the increasing emphasis placed on evidence-based health care. Insurance companies and individuals paying for health care today often insist that physicians justify their clinical judgments regarding the prescription of therapies. A good argument can be made for evidence-based decision-making based on the governance of our God-given resources; however, the actual trend toward evidence-based medicine arose for more than just financial reasons, being rooted in the hungriness to provide patients with the safest, most effective therapies.

The new millennium is ending the free ride that alternative medicine has enjoyed thus far. The claimed binding between spirituality 
Citation: Morales-Borges RH, Rodríguez-Díaz M (2019) Role of Spiritual Medicine as Integrative Medicine in Patients with Cancer (Review). J Altern Complement Integr Med 5: 086.

and health also has not escaped the demand for scientific validation. Researchers have attempted to investigate the impact of spirituality or religion on health and healing via the application of scientific methods. Again, while the renewed attention to matters of faith should be welcomed, Christians should be wary regarding the interpretation and implementation of the results of those studies.

These questions raise some of the core issues requiring attention as health care and spirituality becomes increasingly inter threaded. Christians are called to test the spirits and see if they are from God (1 John 4:1-2). Therefore, Christian health care professionals should be directly involved in speaking to the interface between health and spirituality. The persuasion of alternative medicine has provided them with an opportunity to make their faith more apparent to others. Still, they must also be willing to address the dangers inherent in the improper union of medicine and religion [25].

\section{Oncologic Patients Need Spiritual Support}

Spirituality is the partnership people have with a force or power beyond themselves that helps them feel attached and enrich their lives. Religion is a specific set of beliefs or practices usually affiliated with an organized group. Some people find spirituality by customizing their religious beliefs, while others find it outside of organized religion. Many cancer patients would describe themselves as spiritual, but not necessarily religious, experts say.

People who are already religious often become more deeply religious being diagnosed with cancer, whereas others who were not religious sometimes seek spirituality and a connection to a power outside themselves after the diagnosis. Often people return to the religious traditions of their childhood, experts say. But others may find comfort in a new tradition, such as meditation.

"Spirituality is a chance to be reconnected to God, a religious tradition, and a community that provides hope and strength for the cancer patient" says Rev. Deborah K Davis, director of field education at Princeton Theological Seminary, who was a chaplain at Princeton Medical Center in New Jersey for many years [26].

Experts say that spiritual or religious practices can help you adjust to the effects of cancer and its treatment. Patients who rely on their faith or spirituality tend to experience increased hope and optimism, freedom from regret, higher satisfaction with life and feelings of inner peace. In addition, patients who practice a religious tradition or are in touch with their spirituality tend to be more compliant with treatment and live a healthier lifestyle.

According to the National Comprehensive Cancer Network (NCCN), while a cancer diagnosis can encourage some people to renew their faith, it can have the other effect on others [26]. For them, a diagnosis can contend with their faith and make them doubt their beliefs or religious values. They may become maddened at God or doubt the existence of a higher power. The NCCN says feeling this way can make it harder for patients to cope with cancer and its treatment. It can be helpful and healthy to talk to someone who can understand these feelings of doubt and anger.

Studies show spirituality also can have a direct impact on the quality of life by contributing to your physical health [26]. Among the benefits shown in studies are:
- Decreased feelings of anxiety, depression and anger

- Decreased feelings of loneliness

- Decreased alcohol and drug abuse

- Lowered blood pressure

- Better control of pain, nausea and discomfort

Spirituality may help patients and families find deeper meaning and experience a sense of personal growth during cancer treatment while living with cancer and as a cancer survivor.

Even though there are more cancer survivors today than ever before, a cancer diagnosis is scary for most people because they are suddenly faced with their mortality. They also don't know what to expect from cancer and treatment, although they know it will be challenging.

Often cancer patients report that they feel alone because they believe that no one can truly know what they are going through. Chaplains practice what is called compassionate presence, where they make themselves available to help people with cancer feel more connected to another human being, and perhaps to God, during this part of life's journey, explained Barbara Klimowicz, assistant director of pastoral care and chaplain at Fox Chase Cancer Center in Philadelphia [26].

Many newly diagnosed cancer patients pray for a cure. However, if a cure is not in sight, cancer patients may look for emotional healing and often hope this healing can come from their spiritual relationship? They want to find meaning in their lives and their existence, and they are looking for a sense of support.

End of life decisions have a huge spiritual component. "Deciding what you are going to do or not going to do have a lot to do with deciding what comes next", said Davis. "If you believe something comes next and you are hopeful, then it may be easier for you to let go of futile treatments".

Spiritual practices that may help the patient to cope with cancer and its treatments include:

- Praying alone or with someone else

- Having someone else pray for him/her

- Meditation

- Meditative breathing

- Reading scripture or other holy works

- Saying one passage from their religious tradition over and over again like a mantra

- Using the language of their religion, such as Hebrew, Arabic, or Latin, in their prayers

- Listening to classical or spiritual music

- Yoga

- Talking about spiritual matters with another

\section{Conclusion}

Spiritual medicine is an exciting field that is getting part in gaining more ground in Integrative Medicine models, but it is still falling behind actually in particularly in cancer patients. Oncologic patients need spiritual support, and this should be integrated into our practices. More research studies are also required too to validate this intervention in our patients. 
Citation: Morales-Borges RH, Rodríguez-Díaz M (2019) Role of Spiritual Medicine as Integrative Medicine in Patients with Cancer (Review). J Altern Complement Integr Med 5: 086.

\section{References}

1. https://www.studylight.org/encyclopedias/isb/h/heal.html

2. https://www.bible.com

3. https://dictionary.cambridge.org/us/dictionary/english/spiritual-healing

4. Steinhorn DM, Din J, Johnson A (2017) Healing, spirituality and integrative medicine. Ann Palliat Med 16: 237-247.

5. Tacey D (2011) The spirituality revolution: The emergence of contemporary spirituality. Routledge Taylor \& Francis group, UK.

6. Gorsuch RL, Miller WR (1999) Assessing spirituality. In Miller WR (Ed.) Integrating spirituality into treatment: Resources for practitioners. American Psychological Association, Massachusetts, USA.

7. Butlin H (2015) Psycho-oncology: Searching for practical wisdom? Palliative and Supportive Care 13: 1495 - 1500.

8. Pischke K (2015) Integrative \& Holistic Oncology Nursing. Beginnings 35: $18-20$.

9. Taylor EJ, Amenta M, Highfield M (1995) Spiritual care practices of oncology nurses. Oncol Nurs Forum 22: 31-39.

10. Aldridge D (1991) Spirituality, healing and medicine. British Journal of General Practice 41: 425-427.

11. Ben-Arye E, Schiff E, Vintal H, Agour O, Preis L, et al. (2012) Integrating complementary medicine and supportive care: patients' perspectives toward complementary medicine and spirituality. J Altern Complement Med 18: 824-831.

12. Fortin AH, Barnett KG (2004) Medical School Curricula in Spirituality and Medicine. JAMA 291: 2883.

13. Puchalski CM, Blatt B, Kogan M, Butler A (2014) Spirituality and Health: The Development of a Field. Acad Med 89: 10-16.
14. https://divinity.duke.edu/academics/certificate-theology-and-health-care

15. https://www.csh.umn.edu

16. https://mghihp.edu/mindbodyhealthandhealing

17. https://www.coursesforsuccess.com/products/certificate-in-spirituality-diploma-online-course?gclid=EAIaIQobChMISJa9kliL3QIVDIgGCh391w_YEAMYAiAAEgInV_D_BwE

18. https://medicine.yale.edu/intmed/genmed/education/medspire

19. Koenig HG (2004) Religion, Spirituality, and Medicine: Research Findings and Implications for Clinical Practice. South Med J 97: 1194-1200.

20. Paul SM, David JP, Teresa AR (2001) Religious Involvement, Spirituality, and Medicine: Implications for Clinical Practice. Mayo Clinic Proc 76: 1225-1235.

21. Ribaudo A, Takahashi M (2008) Temporal Trends in Spirituality Research: A Meta-Analysis of Journal Abstracts between 1944 and 2003. Journal of Religion, Spirituality \& Aging 20: 16-28.

22. Worthington EL (2011) Integration of spirituality and religion into psychotherapy. In Norcross JC, Vanden Bos JR, Freedheim DK (Eds.). History of psychotherapy: Continuity and Change, American Psychological Association, Massachusetts, USA.

23. Puchalski CM (2001) The Role of Spirituality in Health Care. Baylor University Medical Center Proceedings 14: 352-357.

24. Kendrick KD, Robinson S (2000) Spirituality: its relevance and purpose for clinical nursing in a new millennium. Journal of Clinical Nursing 9: 701-705.

25. O’Mathúna DP (2001) Spirituality and Alternative Medicine in the New Millennium. The Center for Bioethics \& Human Dignity 7: 1-7.

26. National Comprehensive Cancer Network (2019) Finding Comfort in Spirituality. National Comprehensive Cancer Network, Pennsylvania, USA. 


\section{Hit \\ HERALD}

Journal of Anesthesia \& Clinical Care

Journal of Addiction \& Addictive Disorders

Advances in Microbiology Research

Advances in Industrial Biotechnology

Journal of Agronomy \& Agricultural Science

Journal of AIDS Clinical Research \& STDs

Journal of Alcoholism, Drug Abuse \& Substance Dependence

Journal of Allergy Disorders \& Therapy

Journal of Alternative, Complementary \& Integrative Medicine

Journal of Alzheimer's \& Neurodegenerative Diseases

Journal of Angiology \& Vascular Surgery

Journal of Animal Research \& Veterinary Science

Archives of Zoological Studies

Archives of Urology

Journal of Atmospheric \& Earth-Sciences

Journal of Aquaculture \& Fisheries

Journal of Biotech Research \& Biochemistry

Journal of Brain \& Neuroscience Research

Journal of Cancer Biology \& Treatment

Journal of Cardiology \& Neurocardiovascular Diseases

Journal of Cell Biology \& Cell Metabolism

Journal of Clinical Dermatology \& Therapy

Journal of Clinical Immunology \& Immunotherapy

Journal of Clinical Studies \& Medical Case Reports

Journal of Community Medicine \& Public Health Care

Current Trends: Medical \& Biological Engineering

Journal of Cytology \& Tissue Biology

Journal of Dentistry: Oral Health \& Cosmesis

Journal of Diabetes \& Metabolic Disorders

Journal of Dairy Research \& Technology

Journal of Emergency Medicine Trauma \& Surgical Care

Journal of Environmental Science: Current Research

Journal of Food Science \& Nutrition

Journal of Forensic, Legal \& Investigative Sciences

Journal of Gastroenterology \& Hepatology Research

Journal of Gerontology \& Geriatric Medicine

Journal of Genetics \& Genomic Sciences

Journal of Hematology, Blood Transfusion \& Disorders

Journal of Human Endocrinology

Journal of Hospice \& Palliative Medical Care

Journal of Internal Medicine \& Primary Healthcare

Journal of Infectious \& Non Infectious Diseases

Journal of Light \& Laser: Current Trends

Journal of Modern Chemical Sciences

Journal of Medicine: Study \& Research

Journal of Nanotechnology: Nanomedicine \& Nanobiotechnology

Journal of Neonatology \& Clinical Pediatrics

Journal of Nephrology \& Renal Therapy

Journal of Non Invasive Vascular Investigation

Journal of Nuclear Medicine, Radiology \& Radiation Therapy

Journal of Obesity \& Weight Loss

Journal of Orthopedic Research \& Physiotherapy

Journal of Otolaryngology, Head \& Neck Surgery

Journal of Protein Research \& Bioinformatics

Journal of Pathology Clinical \& Medical Research

Journal of Pharmacology, Pharmaceutics \& Pharmacovigilance

Journal of Physical Medicine, Rehabilitation \& Disabilities

Journal of Plant Science: Current Research

Journal of Psychiatry, Depression \& Anxiety

Journal of Pulmonary Medicine \& Respiratory Research

Journal of Practical \& Professional Nursing

Journal of Reproductive Medicine, Gynaecology \& Obstetrics

Journal of Stem Cells Research, Development \& Therapy

Journal of Surgery: Current Trends \& Innovations

Journal of Toxicology: Current Research

Journal of Translational Science and Research

Trends in Anatomy \& Physiology

Journal of Vaccines Research \& Vaccination

Journal of Virology \& Antivirals

Archives of Surgery and Surgical Education

Sports Medicine and Injury Care Journal

International Journal of Case Reports and Therapeutic Studies 